\title{
Perancangan Sistem Informasi Berbasis Komputer Untuk Monitoring Aktivitas Di Bengkel Produksi Pada Pembangunan Kapal Baru
}

\author{
Pandu Auditya Pratama, dan Triwilaswandio Wuruk Pribadi \\ Departemen Teknik Perkapalan, Fakultas Teknologi Kelautan, Institut Teknologi Sepuluh Nopember \\ (ITS) \\ e-mail: triwilas@na.its.ac.id
}

\begin{abstract}
Abstrak-Tujuan utama dari studi ini adalah untuk merancang sistem informasi berbasis komputer untuk monitoring aktivitas di bengkel produksi pada pembangunan kapal baru. Pertama, kebiasaan sistem pemantauan yang ada di bengkel produksi perusahaan pembangunan kapal dilakukan observasi. Kedua, sistem informasi berbasis komputer untuk monitoring aktivitas di bengkel produksi pada pembangunan kapal baru direncanakan dengan menggunakan mock up sebagai alat untuk mendesain. Tahap akhir, sistem informasi yang telah dirancang diuji kepada responden. Sistem informasi ini mempunyai fitur untuk mendaftarkan proyek kapal baru dan data kapal, menu untuk memasukan pengguna baru dan pekerja di bengkel, menunjukkan kemajuan progres pembangunan kapal, dan meninjau hasil kegiatan di bengkel sebagai data historis. Sistem ini telah diuji coba kepada responden yang melibatkan beberapa pihak di galangan kapal atau memiliki latar belakang pendidikan di bidang arsitek perkapalan dan pembangunan kapal. Dengan menggunakan kuesioner diperoleh bahwa sistem informasi ini perlu diterapkan untuk mendukung proses pemantauan di bengkel dengan persentase rata-rata nilai $83,34 \%$.
\end{abstract}

Kata Kunci-Sistem Informasi, Monitoring, Manajemen Proyek, Pengawasan Pembangunan Kapal, Aplikasi Komputer.

\section{PENDAHULUAN}

$\mathrm{P}$ ENINGKATAN pemesanan terkait kebutuhan kapal membuat banyak perusahaan galangan kapal semakin terpacu dalam pembangunan proyek kapal baru. Seiring dengan pesatnya kebutuhan akan pembangunan kapal baru tersebut, maka perkembangan industri manufaktur galangan kapal juga mengalami peningkatan. Hal ini tentunya memperoleh perhatian khusus dari pihak internal galangan kapal, perhatian khusus tersebut berupa pengawasan dalam proses pembangunan kapal. Dalam proses pembangunan kapal terdapat bengkel-bengkel produksi yang berperan dalam membentuk suatu badan atau lambung kapal. Pengawasan pada bengkel-bengkel inilah yang perlu dilakukan kontrol secara berkala agar proyek yang dikerjakan sesuai dengan target yang telah direncanakan.

Hal yang terjadi saat ini pada proses pekerjaan pembangunan kapal di galangan kapal seringkali ditemui kesulitan untuk memperoleh informasi secara cepat dan mudah pada tiap-tiap bagian bengkel pengerjaan. Padahal dalam proses pekerjaan bangunan baru di galangan kapal diperlukan sistem informasi yang baik, dikarenakan perencanaan pembagian beban kerja oleh kepala proyek terhadap proyek yang akan dilaksanakan akan berakibat juga pada kelancaran proses produksi, sehingga berpengaruh terhadap waktu penyelesaian pekerjaan yang telah di rencanakan. Selain itu proses pengemasan laporan yang dilakukan secara tertulis juga rawan terjadi kerusakan dan kehilangan.

Dalam studi ini tercetus gagasan untuk merancang sistem informasi untuk monitoring aktivitas di bengkel produksi pada pembangunan kapal baru sebagai penghubung informasi yang efisien, dan selalu ter-update agar pihak internal galangan dapat mengetahui informasi dan memantau aktivitas bengkel secara lebih cepat dan mudah. Hal yang kiranya dipantau dalam pekerjaan di tiap bengkel produksi pada suatu galangan kapal yaitu menelaah proyek apa saja yang dikerjakan, kemudian mengidentifikasi bagaimana proses dan progress yang dikerjakan di tiap bengkel produksi, berapa volume pekerjaan yang ada di tiap bengkel produksi tersebut, siapa saja yang bekerja dan bagaimana jam realisasinya, serta data lain yang kiranya diperlukan dalam tercapainya proses monitoring yang baik untuk memberikan informasi yang berguna.

Selain itu aplikasi ini juga dapat mempermudah kepala bengkel dalam memberikan laporan langsung kepada pihak departemen atau administrator. Administrator berwewenang untuk melihat rekap data hasil inputan oleh user di bengkel serta melakukan registrasi calon user. Dalam ini, departemen PPC lah yang dapat berwewenang sebagai administrator.

Berdasarkan hal tersebut diatas adalah hal yang melatarbelakangi penulis untuk menyusun studi ini sebagai upaya untuk membantu terciptanya sistem penghubung yang efisien antara pihak bengkel produksi dan pihak departemen di dalam perusahaan galangan kapal terkait proses pengawasan terhadap pembangunan kapal baru.

\section{STUDI LITERATUR}

\section{A. Alur Proses Pembangunan Kapal}

Alur produksi sebuah kapal melalui beberapa proses yang meliputi persiapan material hingga proses erection. Berawal dari proses persiapan material yang terdiri dari aktivitas straightening dan blasting shop primer. 
Kemudian proses marking dilakukan yaitu dimana material dilakukan proses penandaan di permukaannya untuk menjadikan acuan pada proses cutting. Berikutnya proses cutting yaitu pemotongan material sesuai dengan marking yang sudah dilakukan sebelumnya, dan terdapat pula proses forming untuk menghasilkan bentuk material yang diinginkan [1].

Lalu pada tahap sub assembly dan assembly aktivitasnya hampir sama, hanya saja yang membedakan adalah jika sub assembly membentuk panel sedangkan pada assembly membentuk blok. Aktivitasnya antara lain yaitu fitting, fitting merupakan penempatan, pemasangan dan peletakan suatu konstruksi yang akan disambung. Lalu proses welding yaitu pengelasan. Terdapat pula proses bending/forming dan fairing yang merupakan proses pemanasan material yang terjadi deformasi untuk mengembalikan part ke bentuk yang diinginkan [2].

Proses yang terakhir yaitu erection yang terdapat serangkaian kegiatan seperti loading, adjusting, fitting dan welding.

\section{B. Manajemen Proyek}

Manajemen proyek merupakan rangkaian proses merencanakan, mengelola, memimpin dan mengendalikan kegiatan-kegiatan personil serta sumber daya lain untuk menangani dan menyelesaikan pembuatan suatu produk atau bisnis [3]. Di dalam manajemen proyek terdapat kegiatan monitoring yang merupakan serangkaian kegiatan yang terdiri dari proses mengamati atau meninjau secara berkala yang dilakukan oleh pengelola proyek di tiap pelaksanaan kegiatan aktivitas pada perusahaan untuk memastikan bahwa hasil yang diperoleh pada hari itu sesuai dengan keinginan.

\section{Konsep Monitoring}

Pengawasan dan pengendalian dalam proses monitoring dibutuhkan untuk menjamin penggunaan sumber daya secara tepat, dengan memberikan pedoman pada performance, quality, retention program, dan quantity [4].

Selain itu terdapat aspek-aspek yang terdapat pada kegiatan monitoring yaitu:

1. Aspek masukan (input) proyek antara lain mencakup tenaga manusia, jam kerja, data, bahan atau material, manajemen dan sebagainya yang dibutuhkan untuk melaksanakan kegiatan proyek.

2. Aspek proses atau aktivitas, yaitu aspek dari proyek yang menggambarkan proses kegitatan, misalnya penelitian, proses produksi, dan lain-lain.

3. Aspek keluaran (ouput) yaitu aspek dari suatu proyek yang berkaitan atau mencakup mengenai hasil dari proses terutama terkait dengan kuantitas/jumlah.

\section{Struktur Data Sistem Informasi}

Struktur data yang ada dalam perancangan sistem informasi meliputi [5]:

1. Entity; atau entitas, menunjukkan objek-objek dasar yang terkait di dalam sistem. Objek dasar dapat berupa orang, benda atau hal lain yang keterangannya perlu disimpan dalam basis data.

2. Attribute; atau atribut, sering juga disebut sebagai property, merupakan keterangan-keterangan yang terkait pada sebuah entitas yang perlu disimpan sebagai penjelas sebuah entitas untuk menggambarkan atribut yang dilakukan.

3. Value; merupakan simbol-simbol yang digunakan untuk atribut dari entitas tertentu, atau nilai dari atribut yang dapat menggambarkan entitas.

4. Relationship; atau hubungan, merupakan kejadian atau transaksi yang terjadi di antara dua entitas yang keterangannya perlu disimpan dalam basis data.

Kemudian terdapat macam-macam hubungan antar entity antara lain yaitu:

Tabel 1.

Macam Hubungan Antar Entitas

\begin{tabular}{cc}
\hline \hline Nama & Contoh \\
\hline $\begin{array}{c}\text { One to one } \\
\text { relationship }\end{array}$ & $\begin{array}{c}\text { Satu mahasiswa memiliki satu nomor induk dan satu } \\
\text { nomor induk mahasiswa hanya dimiliki oleh satu } \\
\text { orang mahasiswa }\end{array}$
\end{tabular}

One to many Seseorang dapat memiliki satu nomor telepon tetapi relationship setiap satu nomor telepon hanya bisa dimiliki oleh seseorang

Many to many Seorang murid mempunyai mata pelajaran lebih dari relationship satu dan satu mata pelajaran dapat diikuti lebih dari satu orang murid

Pada Tabel 1 diatas dijelaskan macam dan contoh hubungan antar entitas yang biasanya terjadi dalam program. Dijelaskan bahwa one to one merupakan tingkat hubungan satu ke satu, lalu one to many memiliki tingkat hubungan satu ke banyak, sedangkan many to many memiliki tingkat hubungan kebanyakan.

\section{E. Software Program}

Sistem informasi dirancang menggunakan text editor yaitu Sublime Text, basis data MySQL, dan bahasa pemrograman PHP. PHP atau PHP Hypertext Preprocessor merupakan bahasa pemograman berbasis server-side yang dapat melakukan pasring script php menjadi script web sehingga dari sisi client menghasilkan suatu tampilan yang menarik. Tujuan utama bahasa ini adalah untuk memungkinkan perancang web untuk menulis halaman web dinamik dengan cepat [6].

\section{METODOLOGI PENELITIAN}

\section{A. Pengumpulan Data dan Studi literatur}

Studi literatur dilakukan dengan mempelajari berbagai bahan acuan seperti jurnal, buku dan referensi lain seperti Studi sebelumnya. Studi literatur bertujuan untuk membantu dalam memahami dan menganalisis permasahalan pada penelitian ini. Selain itu juga dilakukan penelusuran literatur untuk mendapatkan data penunjang.

\section{B. Melakukan Observasi Di Perusahaan}

Tujuan dilakukannya observasi di perusahaan adalah untuk mengetahui kondisi eksisting yang sekarang terjadi di perusahaan tentang bagaimana sistem monitoring yang dilakukan terkait proses kemajuan aktivitas pada tiap bengkel produksi dalam galangan kapal.

\section{Melakukan Pengolahan Data}

Data yang telah didapatkan dari hasil observasi di perusahaan dijadikan sample untuk dimasukkan ke dalam sistem informasi dan diolah agar menjadi keluaran/output dari sistem informasi yang dirancang. 


\section{Merancang Program Sistem Informasi}

Perancangan sistem informasi bermula dari perencanaan alur/skema program yang akan dirancang. Skema tersebut berupa diagram hubungan antar entitas yang direncanakan dalam sistem. Kemudian merancang sebuah rencana awal mengenai tampilan dan parameter-parameter sistem informasi yang tertuang dalam mock up. Tahap selanjutnya yaitu merancang basis data dan pengcodingan sistem informasi.

\section{E. Melakukan Uji Validitas}

Uji validitas dilakukan saat sistem informasi telah selesai dibuat. Tujuannya yaitu untuk mengetes apakah sistem informasi yang telah dibuat dapat berjalan dengan lancar dan sesuai dengan yang diharapkan untuk diimplementasikan nantinya. Uji validitas meliputi uji fungsional program dengan cara me-running satu-persatu menu dalam program serta mengecek apakah output yang dihasilkan oleh program sudah sesuai/benar.

\section{KONDISI EKSISTING PENGAWASAN AKTIVITAS BENGKEL PRODUKSI DI GALANGAN KAPAL}

\section{A. Analisis Kondisi Eksisting Proses Monitoring Galangan} Kapal

Berikut merupakan alur sistem penyampaian informasi yang terjadi di galangan yang akan dijadikan acuan membuat sistem informasi yang didalamnya terdapat user dan hubungannya antar pihak terkait:

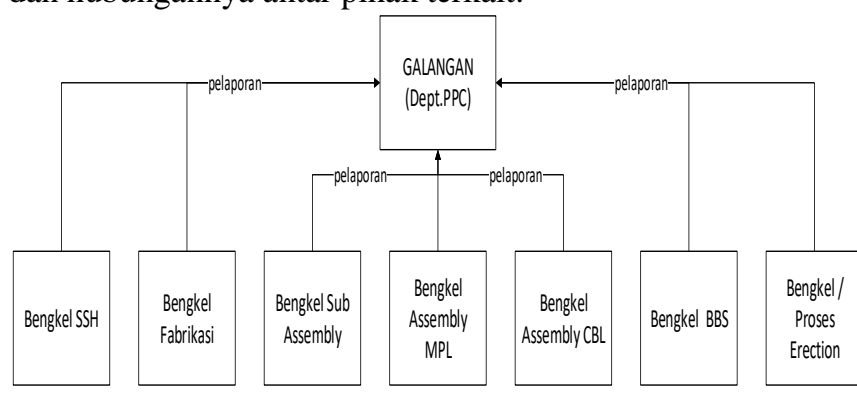

Gambar 1. Alur Sistem Penyampaian Laporan Aktivitas Pada Galangan Kapal

Gambar 1 diatas merupakan hubungan yang ada dalam proses pengawasan di bengkel produksi pada galangan kapal. Setiap bengkel produksi mempunyai kepala bengkel yang bertugas untuk meng-input data dan melaporkan aktivitas pekerjaan yang dilakukan setiap harinya. Setelah itu laporan tadi dilakukan proses analisis dan telaah di dept.PPC dan departemen tersebut melihat progres kemajuan proyek beserta data terkait aktivitas di bengkel.

Kemudian dari hasil survey dan observasi, diketahui terdapat sejumlah kekurangan yang terjadi pada proses pengawasan yang ada saat ini, antara lain:

1. Penyimpanan form laporan pengawasan yang berupa kertas menyebabkan sangat mudah terjadinya kehilangan maupun kerusakan.

2. Penyampaian laporan hanya dapat dilakukan untuk kemajuan proyek tiap minggunya, bukan setiap harinya.

3. Tidak ada sistem penghubung antara pihak bengkel dengan pihak departemen, sehingga informasi tidak dapat dengan langsung bisa menyebar ke pihak-pihak terkait.

\section{B. Pihak Terkait Dalam Proses Pengawasan Aktivitas Bengkel Produksi}

Terkait dengan pemantauan terhadap kemajuan proyek untuk pembangunan kapal baru, di dalam perusahaan terdapat divisi atau pihak terkait yang berperan menjalankan proses monitoring tersebut antara lain:

1. Divisi PPC (Production Planning Control), bertugas dalam proses pengendalian kemajuan proyek, pelaporan kegiatan dan pencapaian sasaran secara periodik.

2. Pimpinan proyek, bertugas mengecek dan merekap perkembangan aktivitas produksi pada setiap harinya untuk menelaah perkembangan proyek.

3. Kepala bengkel, bertugas memantau SDM yang bekerja pada bengkel yang dikomandoinya. Apapun yang berkaitan dengan aktivitas pekerjaan di bengkel ditelaah dan dijadikan laporan kemajuan proyek yang berisikan jam kerja SDM, kendala proses produksi, mesin yang digunakan, serta menuliskan output yang menjadi pekerjaan di tiap-tiap bengkel.

\section{Bengkel-Bengkel Yang Terdapat Pada Proses Produksi}

Pada proses produksi di perusahaan galangan kapal khususnya pada pembangunan Hull Construction, meliputi bengkel persiapan, bengkel fabrikasi, sub-assembly, assembly, block blasting painting, dan proses erection. Aktivitas di tiap-tiap bengkel produksi tersebut antara lain dijelaskan dalam tabel berikut:

Tabel 2.

Aktivitas Tiap Bengkel Produksi

\begin{tabular}{cc}
\hline \hline Nama Bengkel & Nama Aktivitas \\
\hline Bengkel SSH/Persiapan & Pencatatan material datang, \\
Bengkel Fabrikasi & Straightening, Blasting \& ShopPrimer \\
Menking, cutting, bending \\
Fitting, welding, bending, fairing dalam \\
pembentukan panel \\
Bengkel Assembly & Fitting, welding, bending, fairing dalam \\
pembentukan blok \\
Proses Erection & Blasting dan painting \\
\hline \hline
\end{tabular}

Pada Tabel 2 dijelaskan mengenai proses aktivitas yang dilakukan di masing-masing bengkel produksi. Aktivitas tersebut dilakukan secara berurutan hingga proses erection di building berth dilakukan.

\section{Persentase Pembobotan Tiap Aktivitas Pada Bengkel Produksi}

Untuk mengetahui berapa besar persentase pengerjaan aktivitas kemajuan proyek, seringkali di lapangan hanya menggunakan perkiraan. Untuk itu, kedepannya dapat digunakan sistem pembobotan yang jelas melalui kesepakatan bersama terkait kemajuan aktivitas apapun di bengkel produksi. Dengan pembobotan yang jelas melalui kesepakatan bersama, maka dapat dijadikan acuan untuk menentukan berapa persentase kemajuan proyek pada tiaptiap bengkel produksi.

\section{PERANCANGAN SISTEM INFORMASI}

\section{A. Perencanaan Alur Dalam Sistem Informasi}

Alur proses dalam program dapat ditunjukkan melalui pembuatan diagram. Setelah program selesai dibuat, maka diagram yang dapat ditampilkan yaitu PDM (Physical Data Model), sebagai berikut: 


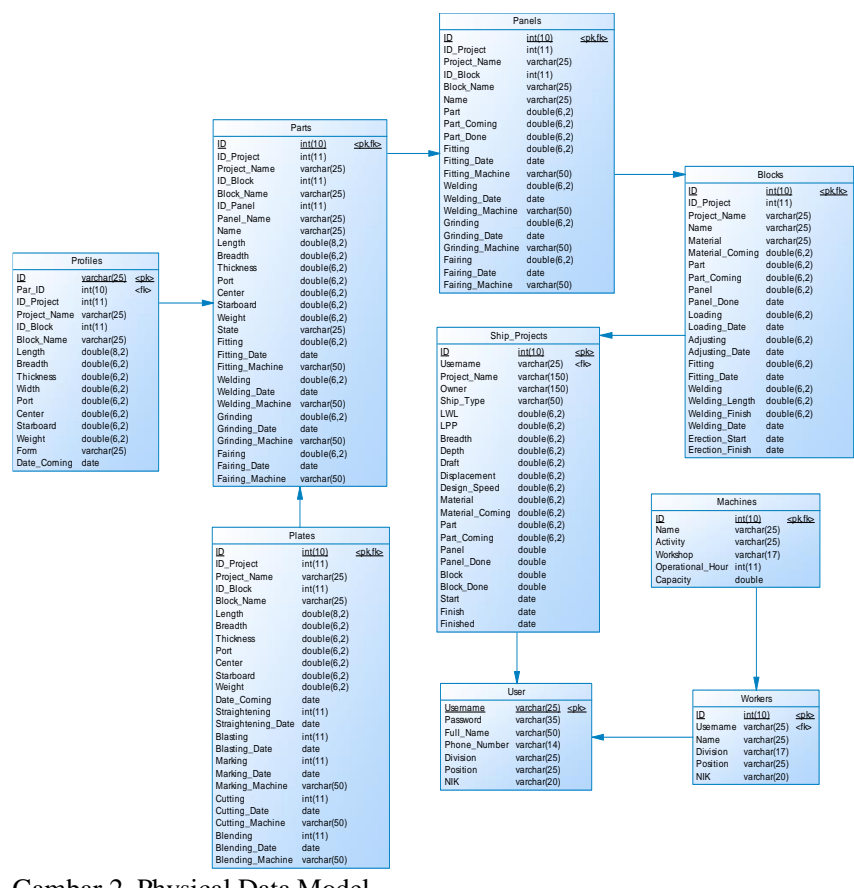

Gambar 2. Physical Data Model

Gambar 2 diatas menunjukkan diagram PDM yang merupakan sebuah representasi seluruh muatan informasi yang dikandung oleh basis data beserta hubungan antar data dalam sistem informasi yang dirancang.

\section{B. Pembuatan Rencana Tampilan Program (Mock Up)}

Mock Up merupakan rancangan awal interface/tampilan yang akan diterapkan pada sistem informasi yang dibuat. Mock up juga berisikan rancangan menu-menu dan atributatribut yang ingin ditampilkan dalam sistem informasi. Berikut merupakan penjelasan singkat mengenai entitas serta wewenang admin dan user pada sistem informasi:

\section{1) Pengguna Sebagai Administrator}

Administrator merupakan bagian yang dapat menggunakan seluruh fasilitas dalam program dan berwenang penuh untuk memasukkan dan menelaah input serta output data di dalam program. Menu yang dirancang untuk admin meliputi create proyek kapal beserta data kapal, create calon user, create pekerja di bengkel, create mesin baru, view proses aktivitas monitoring dan progres kemajuan proyek. Admin dalam sistem informasi yang dibuat dirancang untuk pihak departemen PPC pada perusahaan galangan kapal.

2) Pengguna Sebagai User

User bertugas meng-inputkan data hasil aktivitas pekerjaan di bengkel termasuk pelaporan jikalau terdapat kendala dalam proses produksi. Tiap-tiap bengkel mempunyai hak akses untuk satu bengkel yang menjadi wewenangnya. User dalam sistem informasi yang dibuat dirancang untuk pihak kepala bengkel maupun pihak terkait dalam pengawasan aktivitas di bengkel produksi pada perusahaan galangan kapal.

\section{Merancang Basis Data Dan Pengcodingan Program}

Dalam perancangan program, penulis menggunakan basis data MySQL, berikut merupakan tampilan yang menunjukkan entitas dalam basis data yang dirancang:

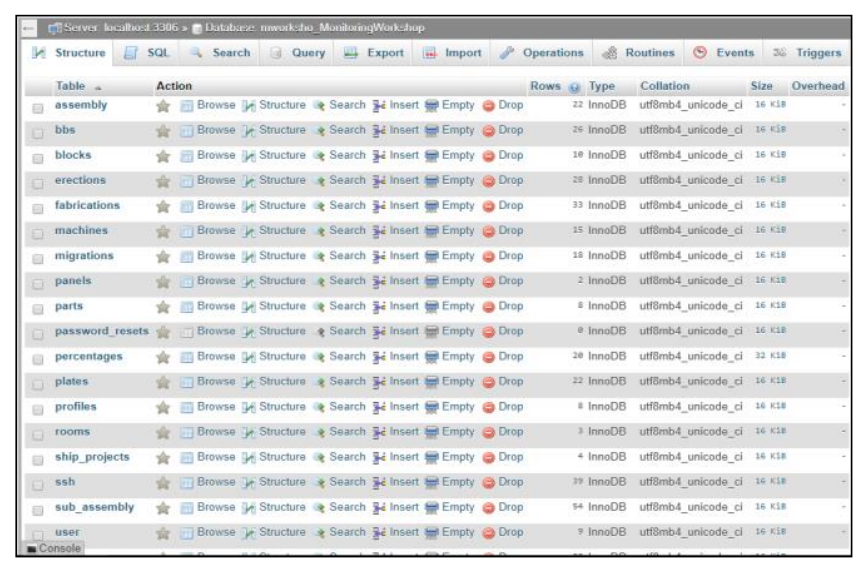

Gambar 3. Daftar Tabel/ Entitas Dalam Basis Data Mysql

Gambar 3 dapat dilihat diatas bahwa didalam setiap tabel entitas akan tersusun dari beberapa atribut beserta query yang nantinya akan ditampilkan di dalam sistem. Atribut tersebut merupakan item yang digunakan dalam setiap tahapan, proses pengawasan, dokumen dan komponen dalam program.

\section{Uji Coba Simulasi Program}

Uji coba simulasi program dimaksudkan untuk memastikan apakah sistem telah berjalan sebagaimana mestinya. Berikut merupakan beberapa tampilan dari sistem informasi yang dirancang:

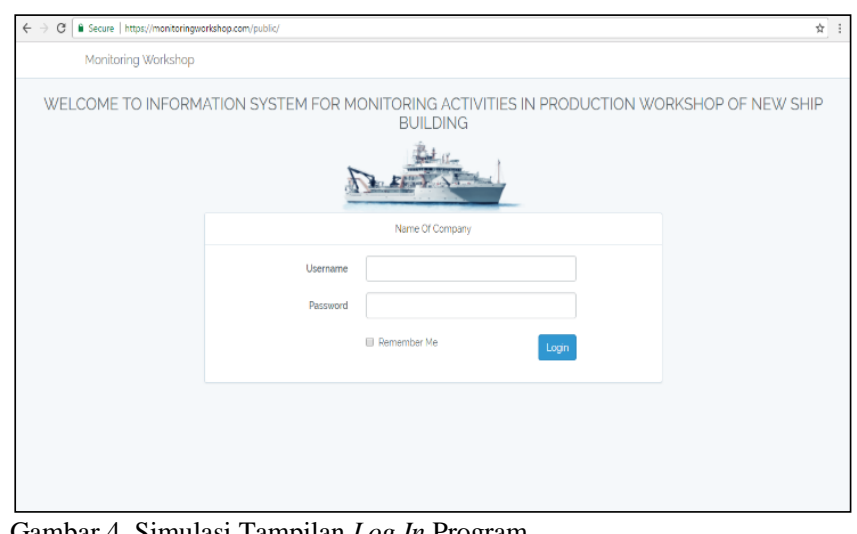

Gambar 4. Simulasi Tampilan Log In Program

Gambar 4 diatas menunjukkan simulasi program pada tampilan admin maupun user pada saat akan melakukan log in ke dalam sistem informasi.

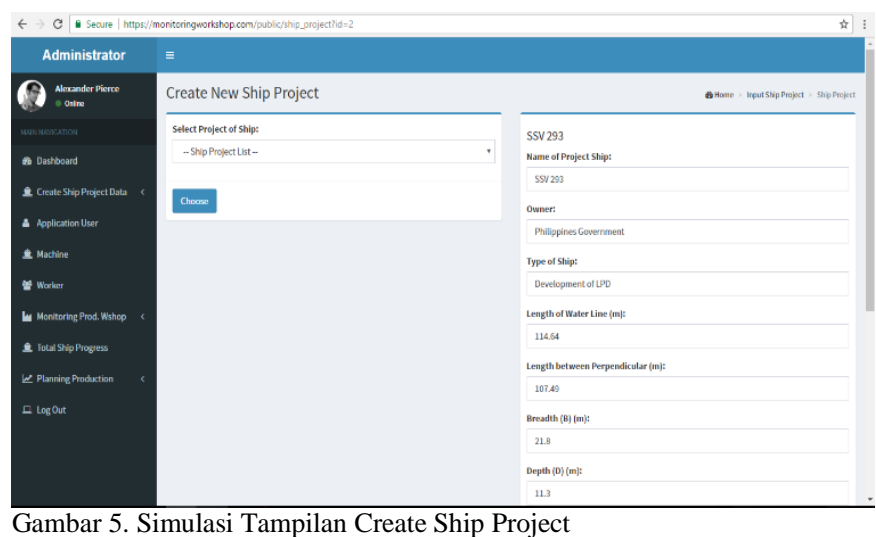

Kemudian pada Gambar 5 merupakan tampilan create ship project yang dilakukan oleh admin. Terdapat parameter berupa nama kapal, jenis kapal, berat konstruksi, panjang,lebar,tinggi kapal, dan lain-lain. 


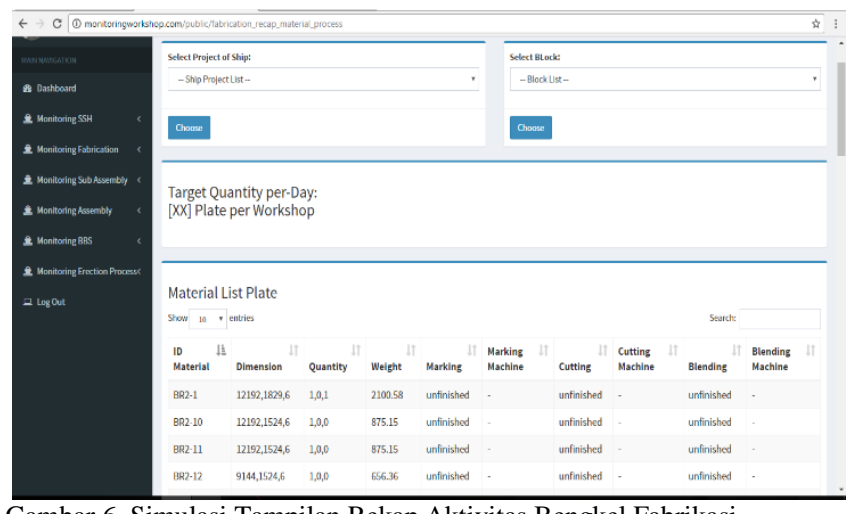

Gambar 6. Simulasi Tampilan Rekap Aktivitas Bengkel Fabrikasi

Lalu contoh lain dari tampilan program terlihat pada Gambar 6 diatas yaitu merupakan tampilan rekap aktivitas dari bengkel fabrikasi. Rekap aktivitas bengkel fabrikasi yaitu proses perlakuan material yang meliputi marking,cutting, dan bending.

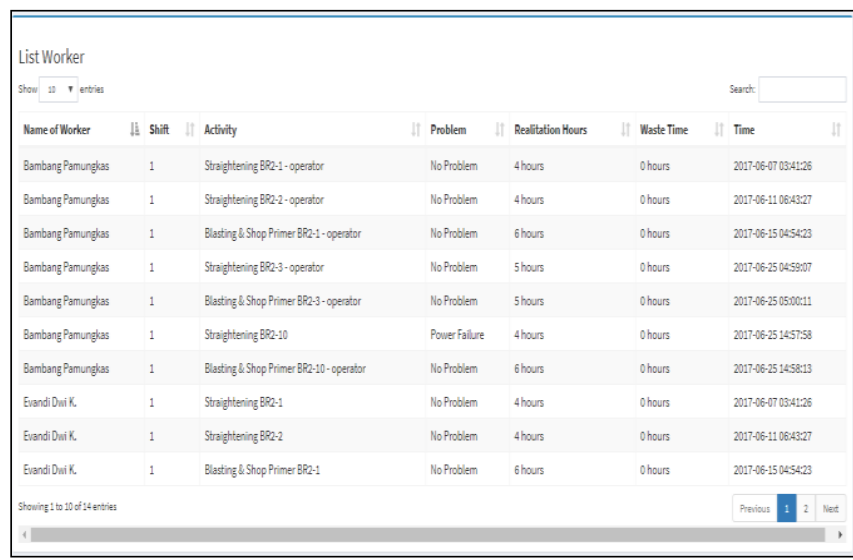

Gambar 7. Simulasi Tampilan Rekap Aktivitas Pekerja

Di dalam program ditambahkan pula fungsi untuk menginput dan melihat data pekerja siapa saja yang terlibat dalam proses aktivitas pengerjaan proyek di bengkel seperti yang terlihat pada Gambar 7 Parameter yang dapat dilihat diantaranya seperti jam realisasi pekerja, tanggal pekerjaan, output hasil bengkel, dan kendala yang terjadi selama proses produksi.

Selain itu, untuk mengetahui berapa persentase kemajuan progres blok kapal pada masing-masing bengkel maka dalam sistem informasi ini ditambahkan menu tersebut. Dengan catatan bahwa tiap persentase aktivitas di bengkel telah disepakati sebelumnya.

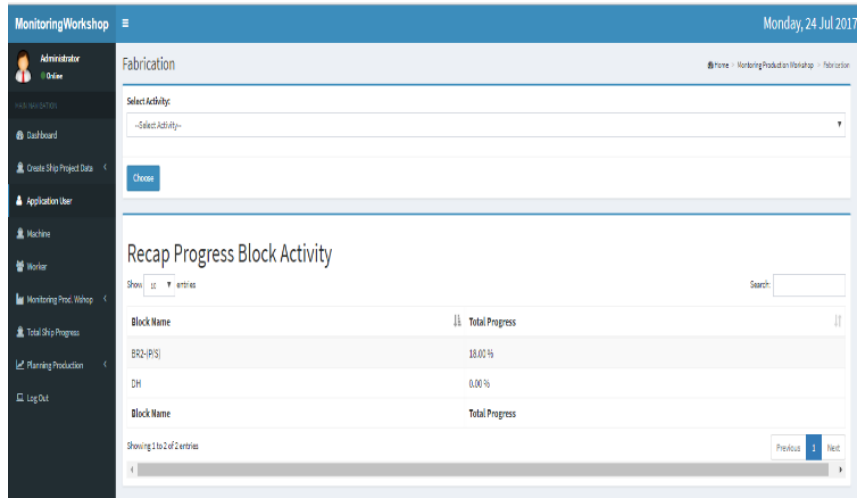

Gambar 8. Simulasi Tampilan Rekap Progres Blok Kapal

Gambar 8 diatas menunjukkan rekap progres pengerjaan blok kapal. Tiap-tiap pengerjaan blok di bengkel tertentu terdapat rekap pekerjaan beserta persentase kemajuan proyek blok kapal tersebut.

\section{ANALISIS DAN UJI COBA SISTEM INFORMASI}

Pada bab ini menjabarkan analisis dan pengujian sistem informasi yang telah dirancang yang meliputi:

\section{A. Analisis Perbandingan Sistem}

Analisis perbandingan sistem menjelaskan perbedaan dari sistem yang ada saat ini dengan sistem aplikasi berbasis komputer yang dirancang.

Tabel 3.

Analisis Perbandingan Sistem

\begin{tabular}{cl}
\hline \hline \multicolumn{3}{c}{ Menggunakan Sistem Manual (Kondisi Saat Ini) } \\
\hline & Penyusunan laporan membutuhkan banyak waktu \\
& Penyampaian laporan dirasa kurang cepat \\
& Review pencarian data historical memakan banyak \\
Kondisi Saat & waktu \\
Ini: & Penyimpanan data laporan berupa kertas dapat rawan \\
& hilang/rusak \\
& Menggunakan Sistem Informasi \\
& Penyusunan dan penyampaian laporan terhitung cepat \\
karena terhubung langsung melalui sistem yang \\
terintegrasi \\
Review historical data bisa di search sewaktu-waktu \\
dengan mudah \\
Penyimpanan data tersimpan rapi di sistem back up \\
historical data \\
Pemantauan terhadap aktivitas bengkel dapat \\
dilakukan secara menyeluruh
\end{tabular}

Dari Tabel 3 dapat dilihat perbandingan antara sistem eksisting dengan sistem aplikasi yang dirancang. Dalam tabel tersebut tercantum pula apa keunggulan yang bisa didapat dari penggunaan sistem informasi.

\section{B. Analisis Aspek Operasional}

Analisis aspek operasional membahas hal-hal apa saja yang berperan penting dalam aspek pengoperasian sistem informasi yang dibuat, antara lain:

1. Brainware, merupakan SDM yang bertugas mengoperasikan sistem informasi.

2. Strategi pengimplementasian sistem informasi, meliputi cara agar calon user dapat dengan mudah mengerti dan paham mengenai alur dan pengoperasian sistem informasi.

3. Menelaah mengenai kendala yang dapat sewaktuwaktu terjadi pada saat pengoperasian program.

\section{Analisis Aspek Ekonomis}

Berikut merupakan hal yang berperan penting dalam analisis aspek ekonomis program yang dibuat antara lain:

Tabel 4.

Komponen Analisis Biaya

\begin{tabular}{lcc}
\hline \hline & Komponen Analisis Biaya & Meliputi: \\
\hline & Merupakan & \\
biaya yang & dikeluarkan & -Pengadaan komputer \\
Biaya & untuk pengadaan & - Langganan akses \\
Pengadaan & fasilitas. & internet \\
& Merupakan biaya & -Biaya listrik \\
Biaya & untuk kegiatan & -Biaya perawatan untuk \\
Operasional & operasional awal & perangkat lunak dan \\
& Merupakan biaya & perangkat keras \\
Biaya & untuk & -Biaya pengembangan \\
Pengembangan & mengembangk-an & aplikasi pada \\
& program & periode tertentu \\
\hline \hline
\end{tabular}


Dapat dilihat dari Tabel 4 bahwa dalam merancang sistem informasi ini memerlukan beberapa biaya untuk menunjang kelancaran penggunaan program.

\section{Uji Coba Sistem Informasi}

Pengujian program dilakukan guna mengetahui kelayakan program dengan menelaah apakah fungsi program telah dapat bekerja dengan baik dan benar. Pengujian verifikasi ini dilakukan dengan cara menggunakan kuesioner yang disebarkan kepada responden yang merupakan calon pengguna sistem informasi.

Kesimpulan dari hasil kuisioner didapatkan nilai 24.99, range ini berarti program perlu/disarankan untuk diterapkan dalam monitoring aktivitas bengkel produksi dengan persentase total sebesar $83.34 \%$.

\section{KESIMPULAN DAN SARAN}

\section{A. Kesimpulan}

Dari analisis yang telah dilakukan maka didapatkan kesimpulan sebagai berikut:

1. Proses monitoring terkait aktivitas bengkel produksi pada pembangunan kapal baru yang ada saat ini memiliki beberapa kelemahan. Proses penyusunan laporan dan pelaporan hasil aktivitas di bengkel dilakukan secara manual sehingga kurang efektif dan memakan waktu yang lama serta rawan terjadi kerusakan dan kehilangan.

2. Sistem informasi yang dirancang dapat mempermudah pelaporan pekerjaan pihak internal galangan. Fitur penyampaian laporan yang terintegrasi antara pihakpihak terkait membuat proses pelaporan menjadi lebih praktis. Data dapat tersimpan rapi serta aman dalam sistem database historical data monitoring activity.

3. Dari nilai rata-rata pada hasil kuisoner yang telah dilakukan, didapatkan nilai kelayakan sebesar 24.99 dari nilai maksimum 30, dapat disimpulkan bahwa aplikasi yang dirancang layak dan diperlukan untuk diimplementasikan pada proses monitoring di bengkel produksi.

B. Saran

Adapun saran dalam penelitian kali ini yaitu:

1. Untuk penelitian selanjutnya diharapkan dapat merancang sistem informasi yang lebih kompleks dan lebih detail mengenai atribut-atribut dan parameter dalam sistem, hal ini dikarenakan sistem informasi ini dapat dikembangkan lebih lanjut untuk kesempurnaan proses monitoring aktivitas di bengkel produksi pada masa-masa mendatang.

2. Sebaiknya dilakukan sosialisasi dan pengenalan program terlebih dahulu terhadap calon pengguna sistem informasi. Dapat dengan cara melakukan training atau membuat buku panduan pengoperasian sistem informasi.

3. User pada sistem informasi ini perlu meng-update atau meng-input proses aktivitas bengkel secara terusmenerus pada setiap harinya. Hal ini agar informasi dapat tersalurkan secara cepat kepada pihak-pihak terkait.

\section{DAFTAR PUSTAKA}

[1] R. C. Storch, R. L., Hammon, C. P., Bunch, H. M., \& Moore Ship Production. Centreville,Maryland: Cornell Maritime Press, 1988.

[2] A. Hidayat, "Scholarship Training Report PT.PAL Indonesia," Inst. Teknol. Sepuluh Nop., 2015.

[3] N. Murdifin, H., \& Mahfud, Manajemen Produksi Modern (Operasi Manufaktur Dan Jasa). Jakarta: Bumi Aksara, 2014

[4] A. Assauri, Pengertian dan Pengawasan Proses Produksi. Jakarta: PT.Rineka Cipta, 2008.

[5] Yakub, Sistem Basis Data (Tutorial Konseptual). Yogyakarta: Graha Ilmu, 2008.

[6] B. Nugroho, Aplikasi Pemrograman Web Dinamis Dengan Php Dan Mysql. Yogyakarta: Gava Media, 2008. 